\title{
PENGARUH VARIASI PENYAJIAN MAKANAN TERHADAP PERSEPSI PENAMPILAN DAN DAYA TERIMA MAKANAN PADA PASIEN ANAK DI RSUD BANYUMAS
}

\section{THE EFFECT OF VARIATION OF FOOD SERVE TO APPEAR PERCEPTION AND ACCEPTANCE FOOD FOR CHILDREN PATIENTS IN RSUD BANYUMAS}

\author{
Shanty Triastuti $^{1 ;}$ Ana Yuliah Rahmawati ${ }^{2}$ dan Sri Noor Mintarsih ${ }^{2}$ \\ ${ }^{1}$ Mahasiswa Jurusan Gizi Poltekkes Kemenkes Semarang \\ ${ }^{2}$ Dosen Jurusan gizi Poltekkes Kemenkes Semarang
}

\begin{abstract}
Background: The remaining food of pediatric patients in the inpatient ward of RSUD Banyumas is still high. In addition, factors related to patient satisfaction are influenced by the appearance of food and how the presentation. Factors that can be used as an enhanced presentation of interest include color, texture, color, large portions, serving and decking of food. One effort to improve the patient's child's acceptance of the food served is to serve an interesting meal. Modification of the shape and appearance of food when presented can attract attention so that children are interested to eat and want to spend the food served.
\end{abstract}

Objective: Knowing the effect variation of food serve to appear perception and acceptance food for children patients in RSUD Banyumas

Research Method: This Research is a kind of experiment with planning of Quasy Experimental. The amount subject of the research is 48 people who have some criteria inclusion. The data included perception of food appearance and food acceptance using Comstock. The statistical test used is chi Square.

Results: The patient's perception of the food appearance was satisfactorily varied at $87.5 \%$. The acceptance of feeding patients given food presentation was varied by $41.7 \%$. There is influence of variation of food presentation to perception of appearance in pediatric patient with $p$ value 0.000 . There was no effect of variation of food presentation on patient's pediatrics, with $p$ value 0.221 .

Conclusion: Variations in food presentation affect the respondent's perception of the appearance of the food served, but it does not affect the acceptance.

Keywords : perception, acceptance of food, variation of food presentation.

\section{ABSTRAK}

Latar Belakang: Sisa makanan pasien anak di ruang rawat inap RSUD Banyumas masih tinggi. Selain itu faktor yang berhubungan dengan kepuasan pasien yang dipengaruhi oleh penampilan makanan dan cara penyajian . Faktor-faktor yang dapat digunakan sebagai peningkatan penyajian yang menarik antara lain adalah warna, tekstur, warna, besar porsi, alat penyajian dan penghiasan makanan. Salah satu upaya untuk meningkatkan daya terima pasien anak terhadap makanan yang disajikan adalah dengan menyajikan makanan yang menarik. Modifikasi bentuk dan tampilan makanan ketika disajikan dapat menarik perhatian sehingga anak tertarik untuk makan dan mau menghabiskan makanan yang disajikan.

Tujuan Penelitian: Mengetahui pengaruh variasi penyajian makanan terhadap persepsi penampilan dan daya terima makanan pada pasien anak di RSUD Banyumas.

Metode Penelitian: Jenis penelitian eksperimen dengan rancangan penelitian Quasy Eksperimental. Jumlah subjek penelitian 48 orang yang memenuhi kriteria inklusi. Data yang diambil meliputi persepsi penampilan makanan dan daya terima makanan menggunakan Comstock. Uji bivariat yang digunakan adalah chi Square. 
Hasil: Persepsi pasien tentang penampilan makanan yang divariasi memuaskan yaitu 87,5\%. Daya terima makanan pasien yang diberi penyajian makanan yang divariasi $41,7 \%$. Ada pengaruh variasi penyajian makanan terhadap persepsi penampilan pada pasien anak dengan $\mathrm{p}$ value 0.000 . Tidak ada pengaruh variasi penyajian makanan terhadap daya terima pasien anak, dengan $p$ value 0.221 .

Kesimpulan:Variasi penyajian makanan mempengaruhi persepsi responden terhadap penampilan makanan yang disajikan, namun tidak berpengaruh terhadap daya terima.

Kata kunci: persepsi, daya terima makanan, variasi penyajian makanan.

\section{PENDAHULUAN}

Penyelenggaraan makanan di rumah sakit dilaksanakan dengan tujuan untuk menyediakan makanan yang kualitasnya baik, jumlah sesuai kebutuhan serta pelayanan yang layak dan memadai bagi pasien yang membutuhkan. Mutu pelayanan gizi yang baik akan mempengaruhi indikator mutu pelayanan Rumah Sakit. Semakin baik kualitas pelayanan gizi rumah sakit semakin tinggi tingkat kesembuhan pasien. Semakin pendek lama rawat inap dan semakin kecil biaya perawatan rumah sakit ${ }^{1}$.

Sisa makanan pasien di rawat inap rumah sakit cenderung masih tinggi. Seperti survei sisa makanan yang dilakukan di RSUD Salewangang Maros di bangsal anak didapatkan hasil bahwa makanan pokok yang dihabiskan hanya $25 \%$, Lauk Hewani $20 \%$, Lauk nabati $27,5 \%$, sayur $17,5 \%$, dan buah $12,5 \% 2$. Berdasarkan penelitan di RSUD Senopati Bantul bahwa sisa lauk nabati pada pasien anak adalah $50 \%{ }^{3}$. Salah satu indikator keberhasilan pemberian makanan di Rumah Sakit adalah Standar Pelayanan Minimal (SPM) sisa makanan. Standar Pelayanan Minimal (SPM) sisa makanan di RSUD Banyumas yang digunakan adalah $20 \%$. Penelitian pendahuluan yang peneliti lakukan di Ruang Rawat Inap Kantil RSUD tentang sisa makanan pasien anak didapatkan hasil sisa makanan pada pasien anak masih tinggi yaitu sebesar 58,1 \%. Sisa makanan yang paling banyak dijumpai pada lauk nabati dan makanan pokok. Sisa makanan tinggi menandakan kurang maksimalnya daya terima pasien.

Menurut Khan (1987), penampilan makanan yang disajikan sangat mempengaruhi indera penglihatan. Indera penglihatan sangat peka terhadap warna makanan, bentuk makanan. Kombinasi warna yang menarik, bentuk yang menarik, perpaduan yang baik antar tekstur makanan, serta konsistensi yang baik dari makanan selera makan konsumen dan juga mampu membuat konsumen menikmati makanan yang disajikan ${ }^{4}$.

Modifikasi penyajian makanan dapat digunakan sebagai upaya untuk meningkatkan daya terima pasien terhadap makanan yang diberikan ${ }^{1}$. Modifikasi penyajian makanan diharapkan juga dapat membantu mencapai Sandar Pelayanan Minimal (SPM) sisa makanan yang diterapkan di rumah sakit.

Menurut Parwati (2013), peningkatan asupan makan anak dapat dilakukan dengan beberapa cara, salah satunya adalah dengan menyajikan makanan yang menarik perhatian ${ }^{5}$. Memberikan variasi bentuk dan tampilan pada makanan saat disajikan dapat dilakukan untuk meningkatkan asupan makan anak di rumah sakit.

Berdasarkan latar belakang diatas, peneliti ingin mencoba melakukan modifikasi penyajian makan kepada pasien di bangsal anak RSUD Banyumas dengan cara memodifikasi bentuk dan penampilan makanan anak. Modifikasi bentuk dan tampilan makanan ketika disajikan diharapkan dapat lebih menarik perhatian sehingga anak tertarik untuk makan dan mau menghabiskan makanan yang di sajikan. Apabila makanan yang disajikan dihabiskan, daya terima makanan memuaskan sehingga asupan gizi pada anak meningkat dan kebutuhan gizi anak dapat tercukupi.

\section{METODE PENELITIAN}

Penelitian ini merupakan penelitian di bidang ilmu gizi , khususnya manajemen penyelenggaraan rumah sakit. Penelitian ini dilaksanakan di Rumah Sakit Umum Daerah Banyumas. Penelitian ini merupakan jenis penelitian eksperimen dengan rancangan penelitian Quasy Eksperimental. Penelitian ini menggunakan dua kelompok sampel, yang dipilih secara random. Kelompok yang diberi perlakuan variasi penyajian makan sebagai kelompok eksperimen, sedangkan kelompok tidak diberi 
perlakuan (penyajian makan standar Rumah Sakit) sebagai kelompok kontrol. Populasi pada penelitian ini adalah pasien anak rawat inap di ruang Kantil, Edelweis, Dahlia dan Thalasemi yang berusia 7-18 tahun bisa membaca dan menulis.

Data yang dikumpulkan dalam penelitian ini terdiri dari data primer yang terdiri dari data identitas sampel, data persepsi, data daya terima , data comstock. Data sekunder terdiri dari jenis makanan dan diit yang dilayani instalasi gizi RSUD Banyumas.

Sampel penelitian akan dibagi menjadi kelompok non perlakuan dan kelompok perlakuan. Kelompok non perlakuan diberi penyajian makan standar RS. Sedangkan kelompok perlakukan diberikan penyajian makan yang sudah divariasi bentuk dan dihias. Kedua kelompok penelitian dibagikan kuesioner persepsi makanan dan diukur daya terima makannya dengan menggunakan formulir Comstock. Data persepsi penampilan makanan dan daya terima makan pasien anak dideskripsikan dengan tabel frekuensi. Untuk melihat pengaruh variasi penyajian makan terhadap persepsi penampilan makanan dan daya terima makan pasien anak dilakukan uji chi square , dengan derajat kepercayaan $95 \%$.

\section{HASIL DAN PEMBAHASAN}

Penelitian dilaksanakan pada bulan Juli Juli 2017 di ruang anak Kantil, Dahlia, Edelweiss dan Talasemi serta di dapur instalasi gizi RSUD Banyumas. Responden dalam penelitian ini sebanyak 48 pasien. Responden tersebut terbagi menjadi kelompok yang mendapatkan penyajian makan standar rumah sakit (24 pasien) dan kelompok yang mendapatkan variasi penyajian makan sebanyak 24 pasien. Penelitian dilakukan 2 kali penyajian makan yaitu makan siang dan makan sore.

1. Karakteristik responden berdasarkan jenis kelamin

Karakteristik responden berdasarkan jenis kelaminnya dapat dilihat dari tabel berikut.

Tabel 1. Karakteristik Responden Berdasarkan Jenis Kelamin

\begin{tabular}{cccccccc}
\hline & \multicolumn{4}{c}{ Perlakuan } & \multirow{2}{*}{ Total } \\
\cline { 3 - 7 } & & \multicolumn{3}{c}{$\begin{array}{c}\text { Non } \\
\text { perlakuan }\end{array}$} & \multicolumn{2}{c}{ Perlakuan } & \\
\cline { 3 - 7 } & $\mathrm{N}$ & $\%$ & $\mathrm{n}$ & $\%$ & $\mathrm{n}$ & $\%$ \\
\hline Jenis & Laki-laki & 12 & $50 \%$ & 11 & $45,8 \%$ & 23 & 47,9 \\
Kelamin & Perempuan & 12 & $50 \%$ & 13 & $54,2 \%$ & 25 & 52,1 \\
\hline & Total & 24 & $100 \%$ & 24 & $100 \%$ & 48 & $100 \%$ \\
\hline
\end{tabular}

Dari tabel diatas dapat diketahui bahwa sebagian besar responden berjenis kelamin perempuan yaitu $52,1 \%$. Responden yang mendapatkan perlakuan 45,8 \% (11 orang) berjenis kelamin laki -laki, sedangkan 54,2 \% (13 orang) berjenis kelamin perempuan.

Jenis kelamin merupakan faktor intrinsik dari yang mempengaruhi daya terima. Hal ini disebabkan karena kebutuhan zat-zat gizi berbeda antara pria dan wanita. Perbedaan ini disebabkan oleh umur, tinggi badan, yang mempunyai komposisi tubuh yang berbeda. Untuk zat-zat gizi tertentu wanita memerlukan lebih banyak daripada pria ${ }^{6}$.

\section{Karakteristik responden berdasarkan Usia}

Berdasarkan kelompok umur, sebagian besar responden pada penelitian ini temasuk dalam kategori remaja awal yaitu 25 responden (52,1\%). Menurut Depkes, 2009, yang temasuk dalam kategori remaja awal adalah usia 12-16 tahun. Sebagian besar responden yang diberi perlakuan termasuk dalam kategori kanak - kanak $(54,2 \%)$ atau sebanyak 19 orang, sedangkan responden yang diberi non perlakuan sebanyak 14 orang $(58,3$ \%) termasuk dalam kategori remaja awal. Responden yang paling sedikit dalam penelitian ini adalah remaja akhir (17-25 tahun).

Karakteristik responden berdasarkan usia dapat dilihat dari Tabel 3 berikut ini : 
Tabel 2. Karakteristik Responden Berdasarkan Usia

\begin{tabular}{llllcccc}
\hline & & \multicolumn{2}{c}{$\begin{array}{c}\text { Non } \\
\text { perlakuan }\end{array}$} & \multicolumn{2}{c}{ Perlakuan } & \multicolumn{2}{c}{ Total } \\
\cline { 3 - 8 } & & $\mathrm{n}$ & $\%$ & $\mathrm{n}$ & $\%$ & $\mathrm{n}$ & $\%$ \\
\hline $\begin{array}{l}\text { Kategori } \\
\text { Umur }\end{array}$ & $\begin{array}{l}\text { Kanak-kanak } \\
\begin{array}{l}(5-11 \text { tahun) } \\
\text { Remaja awal }\end{array}\end{array}$ & 6 & $25 \%$ & 14 & $54,2 \%$ & 19 & $39,6 \%$ \\
& $\begin{array}{l}\text { (12-16 tahun) } \\
\text { Remaja akhir } \\
(17-25 \text { tahun })\end{array}$ & 4 & $16,7 \%$ & 0 & $0 \%$ & 4 & $8,3 \%$ \\
\hline & Total & 24 & $100 \%$ & 24 & $100 \%$ & 48 & $100 \%$ \\
\hline
\end{tabular}

A. Analisis Univariat

1. Persepsi pasien tentang penampilan makanan pada hidangan

Persepsi adalah gambaran seseorang tentang objek, orang dan kejadian yang dipengaruhi oleh latar belakang dan status emosinya. Interaksi dan komunikasi merupakan suatu bentuk persepsi. Pelayanan yang diberikan rumah sakit, termasuk pelayanan gizi dan penyelenggaraan makanan juga sangat mempengaruhi persepsi pasien. Persepsi pasien berupa ekspresi tingkat kepuasaan mengenai pelayanan yang telah diberikan. Dari hasil penelitian yang telah peneliti lakukan diketahui bahwa sebanyak $87.5 \%$ responden pada kelompok perlakuan menyatakan bahwa persepsi hidangan yang disajikan memuaskan. Hal tersebut dikarenakan makanan yang disajikan dibentuk dan dihias, menarik perhatian pasien anak. Persepsi yang memuaskan menunjukkan bahwa penampilan makanan yang disajikan sudah sesuai dengan yang diharapkan pasien. Sebanyak 33,30 \% responden pada kelompok non perlakuan menyatakan bahwa persepsi makanan yang disajikan kurang memuaskan. Hal tersebut dikarenakan makanan yang disajikan tidak dibentuk dan dihias, sehingga kurang menarik perhatian pasien anak. Persepsi yang kurang memuaskan menunjukkan bahwa penampilan makanan yang disajikan belum sesuai dengan kehendak pasien. Hal tersebut didukung dengan hasil penelitian Asriyentie (2008) di RSUD Lubuk Sikaping yang menunjukkan bahwa sebagian besar responden (64,5\%) memberikan penilaian yang kurang memuaskan terhadap mutu penampilan makanan ${ }^{7}$.

Dari hasil penelitian yang telah dilakukan dapat disimpulkan bahwa persepsi kelompok perlakuan lebih memuaskan dibandingkan dengan kelompok non perlakuan. Hal ini membuktikan bahwa persepsi penyajian makanan yang divariasi lebih baik daripada penyajian standar RS. Hal itu sejalan dengan teori yang disampaikan oleh (Pucket,2004) bahwa cara penyajian makanan akan menentukan penampilan makanan ${ }^{8}$. Persepsi yang memuaskan pada kelompok perlakuan ini juga sejalan dengan penelitian Ernalina (2014) di RSUD Mandau Duri yang menyatakan bahwa dari uji chi square terdapat hubungan yang bermakna antara penampilan makanan yang disajikan terhadap kepuasan pasien ${ }^{9}$.

Persepsi penampilan makanan pada anakanak dapat dipengaruhi oleh faktor jenis kelamin dan umur. Dari hasil penelitian yang telah peneliti dilakukan, didapatkan hasil bahwa pada kelompok usia kanak-kanak berjenis kelamin laki-laki, responden yang mengatakan persepsi penampilan makanan pada kelompok perlakuan memuaskan sebesar 77,8 \%. Persepsi yang memuaskan pada kelompok usia kanak-kanak dikarenakan pada usia ini (7-11 tahun), anak-anak menyukai makanan berawal dari pandangan visual (penampilan) terlebih dahulu dibandingkan dengan rasa. Penampilan makanan tidak terlepas dari warna makanan tersebut. Warna makanan dapat mempengaruhi selera makan anak. Jika warna makanan tidak sesuai dengan harapan anak, dimungkinkan anak menganggap makanan tersebut mempunyai rasa yang berbeda, sehingga anak tidak berselera untuk memakannya ${ }^{10}$.

Hasil penelitian yang telah dilakukan, menunjukkan bahwa persepsi penampilan pada kelompok perempuan lebih tinggi dari laki-laki. Hal tersebut disebabkan karena anak perempuan biasanya suka dengan sesuatu yang terkesan imut dengan warna-warni cerah. Warna yang cerah juga berefek menstimulasi visual si anak yang masih 
dalam masa tumbuh-kembang agar lebih cepat mengenali aneka bentuk dan warna ${ }^{11}$.

\section{Daya Terima Makanan}

Daya terima makan pasien adalah penerimaan seseorang terhadap makanan yang dihidangkan di suatu penyelenggaraan makanan.

Menurut Supariasa, daya terima makanan seseorang dapat dilihat dari beberapa banyak orang tersebut dapat menghabiskan makanannya dengan menggunakan metode melihat sisa makanan dan mengestimasinya dengan cara taksiran visual menggunakan skala Comstock 6 point. Berikut ini adalah distribusi daya terima pada kelompok perlakuan dan non perlakuan. Tabel 3. Daya Terima Pasien pada kelompok perlakuan dan non perlakuan.

\begin{tabular}{llcccc}
\hline & & \multicolumn{2}{c}{ Non Perlakuan } & \multicolumn{2}{c}{ Perlakuan } \\
& & $\mathrm{n}$ & $\%$ & $\mathrm{n}$ & $\%$ \\
\hline Daya & Baik $<20 \%$ & 6 & $25 \%$ & 10 & $41,7 \%$ \\
Terima & Kurang baik $\geq 20 \%$ & 18 & $75 \%$ & 14 & $58,3 \%$ \\
\hline & Total & 24 & $100 \%$ & 24 & $100 \%$ \\
\hline
\end{tabular}

Pada tabel diatas menunjukkan bahwa daya terima makanan pada kelompok perlakuan daya terima makanan lebih baik yaitu sebesar 41,7 $\%$. Penelitian ini sejalan dengan penelitian menurut Winata (2011), penampilan makanan yang menarik akan meningkatkan selera makan pasien dalam mengonsumsi makanan yang dihidangkan di rumah sakit ${ }^{12}$. Sehingga, modifikasi tertentu terhadap suatu makanan dapat meningkatkan daya terima pasien di rumah sakit ${ }^{11}$.

Daya terima makanan pada kelompok non perlakuan termasuk kategori kurang baik yaitu sebesar 75 \%. Hal tersebut dikarenakan pada penyajian makan non perlakuan, makanan tidak di bentuk maupun dihias, sehingga tidak menarik perhatian anak. Hasil penelitian ini juga didukung oleh Alzubaidy (2008) yang menyatakan bahwa penyajian makanan yang buruk dapat berdampak pada banyaknya sisa makanan pasien ${ }^{13}$.

Hasil penelitian mengungkapkan bahwa daya terima makanan baik pada kelompok perlakuan sebanyak 44,4 \% laki-laki dan $75 \%$ perempuan. responden daya terima makanannya baik pada kelompok perlakuan. Dengan demikian Daya terima makanan pada kelompok responden perempuan lebih tinggi dibandingkan dengan daya terima responden laki-laki.

\section{Daya Terima Makanan Pada Berbagai Jenis Hidangan Pada Kelompok Non Perlakuan dan Kelompok Perlakuan}

Daya terima makan adalah penerimaan seseorang terhadap makanan yang dihidangkan di suatu penyelenggaraan makanan. Berdasarkan hasil penelitian yang telah dilakukan, berikut ini adalah daya terima makanan pada setiap hidangan pada kelompok non perlakuan dan perlakuan.

\section{a. Daya Terima Nasi}

Dari grafik dibawah ini diketahui bahwa pada kelompok perlakuan daya terima nasinya lebih tinggi yaitu sebesar $37,5 \%$. Daya terima nasi pada penyajian makan yang divariasi lebih tinggi karena nasi dibentuk sedemikian rupa menyerupai karakter binatang, boneka, sehingga lebih menarik dan dapat meningkatkan selera makan pasien. Hal ini sejalan dengan penelitian yang sudah dilakukan Widyaningtyas (2013), bahwa daya terima nasi pada penyajian bento $21,87 \%$ lebih tinggi dibandingkan dengan penyajian standar ${ }^{14}$.

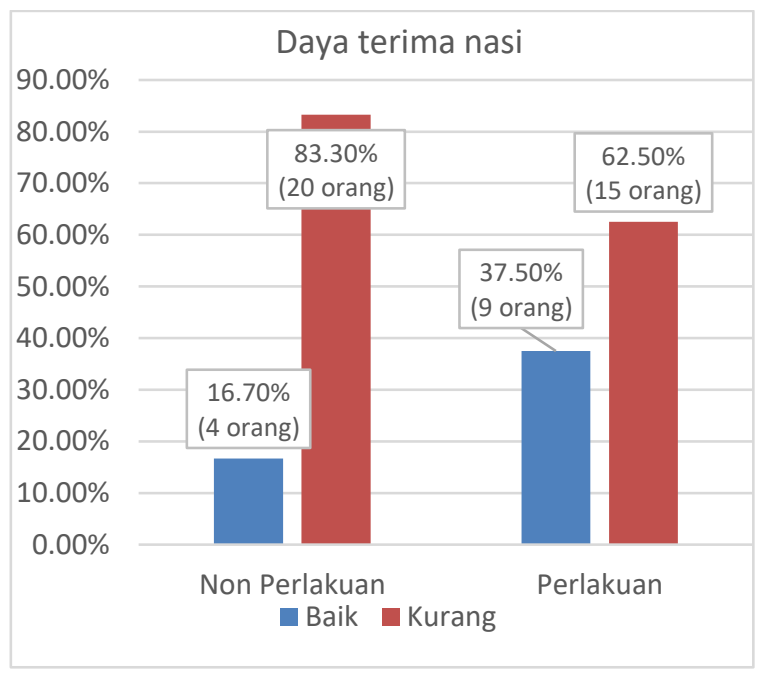

Gambar 1. Grafik Daya Terima Nasi Pada Kelompok non perlakuan dan perlakuan

Dari hasil penelitian didapatkan hasil bahwa kelompok perlakuan daya terima nasi baik pada respoden laki-laki sebanyak umur kanakkanak berjenis kelamin laki-laki sebanyak 44,4\% , sedangkan pada responden perempuan sebanyak $75 \%$ daya terima nasi nya baik. Dari hasil penelitian didapatkan hasil bahwa kelompok 
kanak-kanak berjenis kelamin perempuan daya terima nasi lebih tinggi dibandingkan kelompok laki-laki. Hal tersebut disebabkan karena anak perempuan biasanya suka dengan sesuatu yang terkesan imut dengan warna-warni cerah.

\section{b. Daya Terima Lauk Hewani}

Dari grafik dibawah ini diketahui bahwa daya terima lauk hewani pada kedua kelompok penelitian tidak berbeda jauh. Pada kelompok perlakuan daya terimamya lebih tinggi dibandingkan keompok non perlakuan. Hal tersebut sejalan dengan penelitian Prastuti (2005) yang menunjukkan bahwa daya terima lauk hewani tinggi sebesar 90,48 \%. Dari pengamatan yang dilakukan peneliti, diketahui bahwa sisa lauk hewani paling banyak di jumpai pada saat menu fish roll lada hitam $(29,2 \%)$ dan menu otak-otak tuna $(16,7 \%)^{15}$. Daya terima yang baik pada lauk hewani yang bentuk tampilannya divariasi, dikarenakan penampilan lauk hewaninya menarik, sehingga menyebabkan anak berselera makan. Lauk hewani dibentuk dengan aneka karakter seperti binatang, bunga dan bintang.

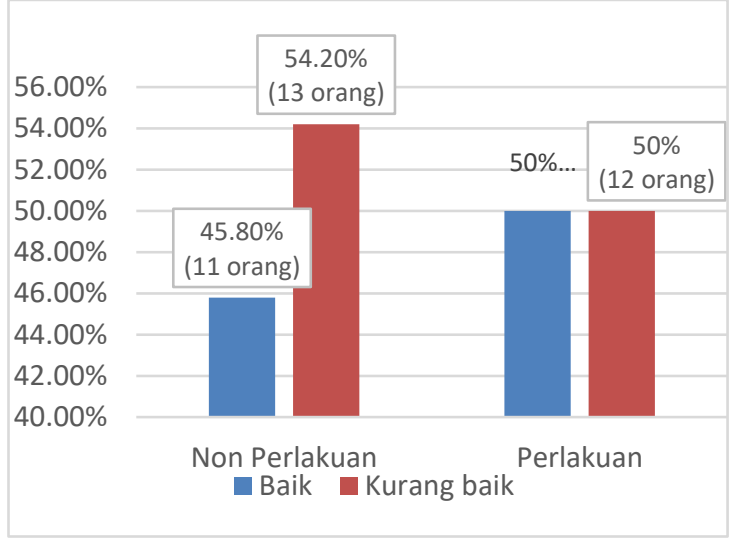

Gambar 2. Grafik Daya Terima Lauk Hewani Pada Kelompok non perlakuan dan perlakuan.

\section{c. Daya Terima Lauk Nabati}

Daya terima lauk hewani pada kelompok non perlakuan dan perlakuan dapat dilihat dari grafik di bawah ini.

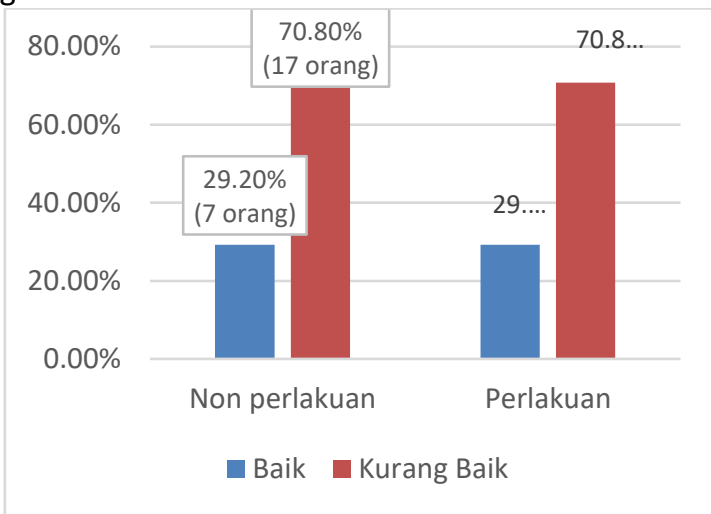

Gambar 3. Grafik Daya Terima Lauk Nabati Pada Kelompok non perlakuan dan perlakuan

Grafik diatas menunjukkan bahwa daya terima lauk nabati pada kelompok perlakuan prosentasenya sama dengan kelompok non perlakuan yaitu memuaskan 29, 2 \%. Dari hasil kuesioner persepsi yang dibagikan kepada responden, diketahui 20,8 \% (5 responden) yang mendapatkan penyajian makan standar mengatakan besar porsi makanan yang disajikan terlalu berlebih, hal tersebut yang menjadikan daya terima makanan khususnya lauk nabati kurang baik. Porsi makanan yang terlalu besar dan kecil akan mempengaruhi penampilan makanan ${ }^{1}$.

Hasil penelitian menujukkan bahwa kelompok umur kanak-kanak berjenis kelamin lakilaki sebanyak $44.4 \%$ responden daya terima lauk nabatinya baik pada kelompok perlakuan. Sedangakan $55.6 \%$ daya terima lauk nabati kurang baik pada kelompok perlakuan. Pada penelitian ini untuk kelompok perlakuan penampilan lauk nabati dibentuk aneka karakter seperti bintang, bunga, dll.

Dari penelitian yang telah dilakukan diketahui bahwa kelompok umur kanak-kanak berjenis kelamin perempuan sebanyak $75 \%$ responden daya terima lauk nabatinya kurang baik pada kelompok perlakuan. Sedangkan pada kelompok remaja awal berjenis kelamin perempuan $77.8 \%$ responden daya terima lauk nabatinya kurang baik pada kelompok perlakuan. Kurangnya daya terima lauk nabati pada kedua kelompok dikarenakan menu nabati yang disajikan berupa tahu dan tempe yang tidak dimodifikasi resepnya sehingga menimbulkan kebosanan. Menu 
tersebut sama dengan yang responden konsumsi sehari-harinya.

\section{d. Sayur}

Daya terima sayur pada kelompok non perlækuan dan perlakuan dapat dilihat dari grafik di bawah ini.

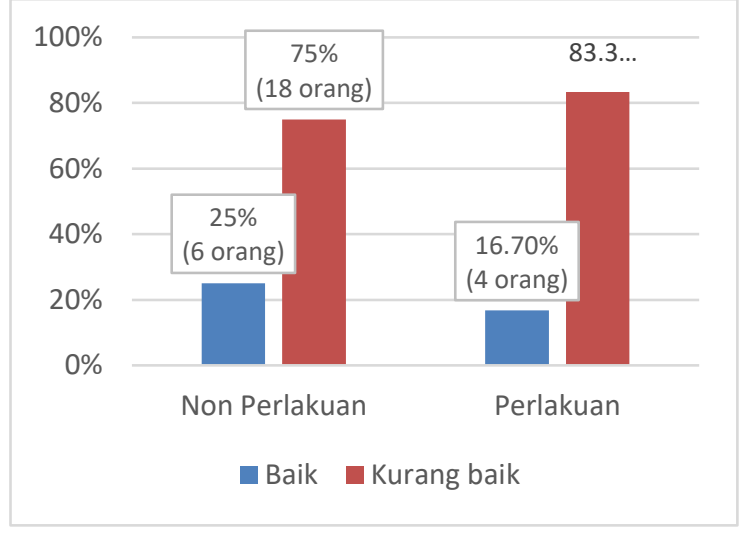

Gambar 4. Grafik Daya Terima Sayur Pada

Kelompok non perlakuan dan perlakuan

Grafik diatas menunjukkan bahwa pada kelompok non perlakuan daya terima sayur $25 \%$ kurang baik. Sedangkan pada kelompok perlakuan daya terima sayur sebanyak 16,7 \% kurang baik. Hal tersebut dapat disebabkan karena sayur untuk 2 kelompok tersebut tidak dibedakan perlakuannya. Pada saat penelitian sayur kelompok perlakuan tidak dibentuk maupun dihias.

Sayur memiliki daya terima yang kurang karena teksur berserat dan rasanya yang tidak enak. Hal ini didukung oleh Hendrayati (2009) yang menyatakan bahwa sayur memiliki daya terima yang rendah karena rasa, bentuk dan warnanya tidak terlalu disukai anak ${ }^{2}$. Selain itu daya terima yang rendah juga dapat disebabkan karena kebiasaan pasien yang jarang mengkonsumsi sayur 16. Hasil penelitian mendapatkan hasil bahwa kelompok umur kanak-kanak berjenis kelamin lakilaki sebanyak 66,7 \% responden daya terima sayurnya kurang baik pada kelompok non perlakuan. Sedangkan pada kelompok remaja awal berjenis kelamin laki-laki $71,4 \%$ responden daya terima sayur kurang baik pada kelompok perlakuan. Kurangnya daya terima sayur pada kedua kelompok dikarenakan sayur yang dihidangkan pada kedua kelompok penelitian tidak dibentuk dan dihias. Daya terima sayur kurang disebakan karena anak tidak suka makan sayur. Dari hasil penelitian dan pengalaman klinis, didapatkan sekitar $30 \%$ anak yang mengalami gangguan proses makan dimulut yang selanjutnya akan mengakibatkan gangguan mengunyah dan menelan.

\section{Buah}

Hasil penelitian menunjukkan bahwa daya terima buah pada kelompok perlakuan sebesar $54,3 \%$ daya terima buah termasuk baik. Hal tersebut dapat dikarenakan penampilan buah yang dibuat menarik sehingga membuat anak berselera untuk memakananya. Daya terima buah yang baik juga dapat disebabkan karena pasien suka dengan buah. Hasil penelitian ini sejalan dengan penelitian Nida (2001) yang menyatakan bahwa daya terima buah merupakan daya terima yang paling tinggi ${ }^{16}$. Buah memiliki daya terima yang tinggi karena penampilan, warna yang menarik dan kebiasaan sehari-hari pasien yang menyukai buah. Hasil penelitian ini sejalan dengan penelitian yang dilakukan Widyaningtyas (2014) di RSUP Sardjito yaitu ada peningkatan daya terima buah pada penyajian bento ${ }^{14}$.

Dari hasil penelitian diketahui bahwa kelompok remaja awal berjenis kelamin laki-laki 50 $\%$ responden daya terima buah baik pada kelompok perlakuan. Daya terima buah yang disajikan disebabkan pada kelompok perlakuan buah dibentuk dan dihias sehingga menarik responden.Dari hasil penelitian diketahui bahwa kelompok umur kanak-kanak berjenis kelamin perempuan sebanyak $75 \%$ responden daya terima buahnya baik pada kelompok perlakuan. Sedangkan pada kelompok remaja awal berjenis kelamin perempuan $44.4 \%$ responden daya terima buah baik pada kelompok perlakuan. Daya terima buah yang disajikan baik disebabkan pada kelompok perlakuan buah dibentuk dan dihias sehingga menarik responden. Pada kelompok perlakuan berdasarkan umur kanak-kanak daya terima buah lebih tinggi pada kelompok jenis kelamin perempuan dibandingkan dengan laki-laki. 
B. ANALISI BIVARIAT

1. Pengaruh Variasi Penyajian Makan Terhadap Persepsi Penampilan Pada Pasien Anak
Untuk mengetahui pengaruh variasi penyajian makanan terhadap persepsi penampilan pada pasien anak, digunakan uji chi square.

Tabel 4. Analisis Pengaruh Penyajian Makanan Terhadap Persepsi Penampilan Pada Pasien.

\begin{tabular}{|c|c|c|c|c|c|c|c|}
\hline \multirow[t]{3}{*}{ Persepsi penampilan } & \multicolumn{4}{|c|}{ Perlakuan } & \multirow{2}{*}{\multicolumn{2}{|c|}{ Total }} & \multirow[t]{3}{*}{ P value } \\
\hline & \multicolumn{2}{|c|}{ Non perlakuan } & \multicolumn{2}{|c|}{ Perlakuan } & & & \\
\hline & $\mathrm{n}$ & $\%$ & $\mathrm{n}$ & $\%$ & $\mathrm{n}$ & $\%$ & \\
\hline $\begin{array}{l}\text { Memuaskan } \\
\geq 80 \%\end{array}$ & 8 & 33,3 & 21 & 87,5 & 29 & 60,4 & \\
\hline $\begin{array}{l}\text { Kurang memuaskan } \\
<80 \%\end{array}$ & 16 & 66,7 & 3 & 12,5 & 19 & 39,6 & 0,000 \\
\hline Total & 24 & 100 & 24 & 100 & 48 & 100 & \\
\hline & & & & & & $\begin{array}{l}\text { a awal } \\
\text { a akhir }\end{array}$ & $\begin{array}{l}0,013 \\
-\end{array}$ \\
\hline
\end{tabular}

$(p<0,05)$ yang artinya adalah ada pengaruh variasi penyajian makan terhadap persepsi penampilan makanan pada pasien anak. Hal ini sejalan dengan penelitian Widyaningtyas (2013) di RSUP Dr.Sardjito tentang penyajian makan bento terhadap persepsi pasien yang mendapatkan hasil bahwa ada perbedaan persepsi antara kedua kelompok penelitian $(p 0,0003<p 0,05)^{14}$.

Tabel 5. Hasil Analisa Pengaruh Variasi Penyajian Makanan Terhadap Persepsi Penampilan Makanan Berdasarkan Kelompok Umur dan Jenis Kelamin.

\begin{tabular}{|c|c|c|}
\hline Jenis Kelamin & Kategori umur & $P$ value \\
\hline \multirow[t]{3}{*}{ Laki-laki } & Kanak-kanak & 0,018 \\
\hline & Remaja awal & 0,023 \\
\hline & Remaja akhir & - \\
\hline Perempuan & Kanak-kanak & 0,053 \\
\hline
\end{tabular}

Hasil uji statitik dengan uji chi square pada kelompok umur kanak-kanak, remaja awal jenis kelamin laki-laki diperoleh $p$ value $<0,05$ artinya adalah ada pengaruh variasi penyajian makan terhadap persepsi penampilan makanan pada kelompok tersebut. Pada kelompok kanak-kanak berjenis kelamin perempuan $P$ value $>0,05$ artinya tidak ada pengaruh variasi penyajian makan terhadap persepsi makan pada kelompok tersebut.

\section{Pengaruh Variasi Penyajian} Makan Terhadap Daya Terima Pasien Anak

Berdasarkan hasil penelitian yang dilakukan terhadap 48 responden untuk mengetahui pengaruh variasi penyajian makan terhadap daya terima makanan pada pasien anak , didapatkan hasil sebagai berikut :

Tabel 6. Daya terima makanan pada kelompok perlakuan dan non perlakuan

\begin{tabular}{lccccccc}
\hline Daya Terima & \multicolumn{4}{c}{ Perlakuan } & & Total & P value \\
\cline { 2 - 6 } & \multicolumn{2}{c}{ Non perlakuan } & \multicolumn{2}{c}{ Perlakuan } & & & \\
\cline { 2 - 6 } & $\mathrm{n}$ & $\%$ & $\mathrm{~N}$ & $\%$ & $\mathrm{n}$ & $\%$ & \\
\hline $\begin{array}{l}\text { Baik } \\
\geq 20 \%\end{array}$ & 6 & $25 \%$ & 10 & $41,7 \%$ & 16 & $33,3 \%$ & 0,221 \\
$\begin{array}{l}\text { Kurang Baik } \\
<20 \%\end{array}$ & 18 & $75 \%$ & 14 & $58,3 \%$ & 32 & $66,7 \%$ & \\
\hline Total & 24 & $100 \%$ & 24 & $100 \%$ & 48 & $100 \%$ \\
\hline
\end{tabular}


Hasil uji statistik menunjukan $\mathrm{p}$ value $0.221(p<0,05)$ yang artinya tidak ada pengaruh variasi penyajian makan terhadap daya terima makanan pada pasien anak. Hal tersebut tidak sejalan dengan penelitian Widyaningsih (2013) yang menyatakan bahwa ada pengaruh penyajian makan bento terhadap daya terima pasien di RSUP Dr.Sardjito (p 0,001<p0,001) $)^{14}$.

Penampilan makanan bukan menjadi hal utama untuk mempengaruhi daya terima makanan. Menurut Khumaid 1994, ada faktor internal dan faktor eksternal lain yang mempengaruhi daya terima seperti rasa, variasi menu, seleran makan, pola makan, dll yang tidak penulis teliti. Tidak berpengaruhnya variasi penyajian makan terhadap daya terima pada penelitian ini dapat juga dikarenakan usia responden yang digunakan dalam penelitian ini adalah usia remaja awal (12-16 tahun), dimana untuk kelompok usia ini penampilan makanan bukanlah hal utama dalam penerimaan makanan. Penelitian ini juga tidak sejalan dengan winata (2011), yang mengatakan penampilan makanan yang menarik akan meningkatkan selera makan pasien dalam mengkonsumsi makanan yang dihidangkan di rumah sakit ${ }^{12}$. Sehingga, modifikasi tertentu terhadap suatu makanan dapat meningkatkan daya terima pasien di rumah sakit ${ }^{16}$.

Tabel 7. Hasil Analisis Pengaruh Variasi Penyajian Makanan Terhadap Daya Terima Makanan Berdasarkan Kelompok Umur dan Jenis Kelamin

\begin{tabular}{lll}
\hline Jenis Kelamin & Kategori umur & P value \\
\hline Laki-laki & Kanak-kanak & 0,505 \\
& & \\
& Remaja awal & 0,858 \\
& Remaja akhir & - \\
\cline { 2 - 3 } Perempuan & Kanak-kanak & 0,047 \\
& Remaja awal & 0,182 \\
& Remaja akhir & - \\
\hline
\end{tabular}

Hasil uji statitik dengan uji chi square pada kelompok umur kanak-kanak, remaja awal jenis kelamin laki-laki diperoleh $p$ value $>0,05$ artinya adalah tidak ada pengaruh variasi penyajian makan terhadap daya terima makan pada kelompok tersebut. Pada kelompok kanak-kanak berjenis kelamin perempuan Pvalue $=0,047 \quad(p<0,05)$ artinya ada pengaruh variasi penyajian makan terhadap persepsi makan pada kelompok tersebut.

\section{KESIMPULAN}

Sebanyak 87,5 \% responden menilai persepsi penyajian makanan yang divariasi memuaskan sedangkan $66,7 \%$ responden menilai persepsi terhadap penyajian makan standar Rumah Sakit kurang memuaskan.

Sebanyak 41,7 \% responden pada penyajian makanan yang divariasi daya terima makannya baik,sedangkan $25 \%$ responden pada penyajian makanan standar Rumah Sakit daya terima makannya baik.

Ada pengaruh variasi penyajian makan terhadap persepsi penampilan makanan pada pasien anak, dengan $p$ value 0.000 . Ada pengaruh variasi penyajian makan terhadap persepsi penampilan makanan pada kelompok umur kanakkanak berjenis kelamin laki-laki dengan $p$ value 0,018 . Ada pengaruh variasi penyajian makan terhadap persepsi penampilan makanan pada kelompok umur remaja awal berjenis kelamin lakilaki dengan $p$ value 0,023

Tidak ada pengaruh variasi penyajian makan terhadap daya terima pasien anak, dengan p 0.221. Ada pengaruh variasi penyajian makan terhadap daya terima makanpada kelompok umur kanakkanak berjenis kelamin perempuan dengan value 0,047 .

\section{SARAN}

Perlunya modifikasi resep pada lauk nabati dan sayur serta pengadaan alat-alat cetakan nasi, lauk hewani dan nabati yang bermacam-macam. Perlunya dilakukan penelitian lanjut untuk mengetahui pengaruh variasi penyajian terhadap faktor internal dan eksternal daya terima yang lain.

\section{DAFTAR PUSTAKA}

1. Moehyi,Sjahmien.1992.Penyelenggaraan Makanan Institusi dan Jasa Boga.Jakarta: PT Bharata Niaga Media.

2. Hendrayati,Kunaepah,U \&Nur,Firmayana.2009.Gambaran Daya Terima Makanan dan Asupan Zat gizi terhadap Lama Hari Rawat Pasien Anak di RSUD Salewanggang Maros Tahun 2009. Jurnal Media Gizi Pangan,Vol.VIII, Edisi 2, Juli-Desember 2009.

3. Muhlisina, H.I., Prawiningdyah, Y. \& Sulistyowati, Y., 2013. Bantul Efffect Of Variastion Of Vegetal Side Dish Forms On The Accaptance $\mathrm{O}$ Children Patients At RSUD Panembahan. , 8(1), pp.1-9. Available 
at:

http://journal.respati.ac.id/index.php/medi $\mathrm{ka} /$ article/view/76.

4. Khan, Mahmood.1998.Foodservice Manual Operation .New York:Pusblishing by Van Nostand Reinhold Company.

5. Parwati,2012. 45 Bento karakter unik. Jakarta: Kriya Pustaka.

6. Almatsier,S.1992.Jurnal Kesehatan. Journal Gizi Indonesia, 17 ,pp.87-88

7. Asfriyentie, Dessy (2008) Kesesuaian Biaya Makanan dan Mutu Makanan dengan Daya Terima Pasien RSUD Lubuk Sikaping. Skripsi, Universitas Gadjah Mada.

8. Puckett,RP.2004.Food Service Manual For Health Care Institution.Third Edition.San Fransisco: American Hospital Association.

9. Ernalia, yanti.2014.Faktor-faktor Yang Berhubungan Dengan Kepuasan Pasien Di Ruang Penyakit Dalam dan Ruang Bersalin Terhadap Pelayanan Makan Pasien Di RSUD Mandau Duri. Jurnal Gizi Stikes Tuanku Tambusai Riau, Tahun 2014.

10. Veratamala,2017.Penampilan Makanan Bisa Mempengaruhi Nafsu Makan. at https://hellosehat.com/penampilanmakanan-nafsu-makan

11. Renaningtyas, D. \& Prawirohartono, E.P., 2004. Tempe Terhadap Daya Terima. , pp.45-49.

12. Winata, Novida.2011.Bento Tools, Bagian 2.http://mymealbox.com.

13. Alzubaidy, Abdul Aziz (2008) Hubungan Tingkat Kepuasan dengan Sisa

14. Makanan Biasa pada Pasien Rawat Inap di Rumah Sakit Umum Daerah kabupaten Fakfak. Skripsi, Universitas Gadjah Mada

15. Widayaningtyas,2013. Pengaruh Penyajian Ala Bento Terhadap Persepsi dan Daya Terima Pasein Anak Di RSUP DR.Sardjito.Skripsi, Universitas Gadjah Mada.

16. Prastuti, Betty (2005) Faktor-Faktor yang Berpengaruh terhadap Tingkat Daya terima Makanan pada Anak-Anak Prasekolah di Full Day School TKIT Salman Al-Farisi Yogyakarta. Skripsi, Universitas Gadjah Mada 